\title{
Advice for Non-Family Executives in Family Businesses
}

\section{Ritch Sorenson (University of St. Thomas)}

\section{KEYWORDS: Entrepreneurship, Management, Organization, Family Business, Team Development.}

Ritch Sorenson, Professor of Family Business at the University of St Thomas in Minneapolis, once worked at a bank founded by his grandfather. When it closed, he felt a personal loss that persists many years later. Likewise, families who own and run a business often feel a deep connection to their communities, business partners, employees and one another. This can create challenges for outsiders who are hired to help the family business weather financial and competitive pressures, now and in the future. In this discussion, Sorenson shares his insights about how non-family executives can navigate complex family dynamics, help the business thrive financially, develop strategies for the future and groom the next generation of leaders.

\section{More ideas}

College business professors looking for more ideas to enrich the classroom experience can find them here (https://familybusiness.org/eix-in-class) .

Additional Search Terms: entrepreneurship courses, teaching ideas, teaching resources, classroom ideas, entrepreneurship classes, business schools, business school classes, entrepreneurship students, professors 